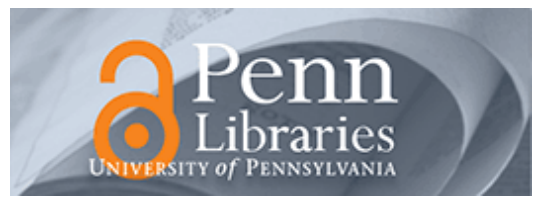

University of Pennsylvania

ScholarlyCommons

9-18-2008

\title{
Does the biomedical revolution spell the end of sport?
}

Arthur L. Caplan

University of Pennsylvania, caplan@mail.med.upenn.edu

Follow this and additional works at: https://repository.upenn.edu/bioethics_papers

\section{Recommended Citation}

Caplan, A. L. (2008). Does the biomedical revolution spell the end of sport?. Retrieved from https://repository.upenn.edu/bioethics_papers/62

Caplan, A L Does the biomedical revolution spell the end of sport? Br J Sports Med 2008 42: $996-997$ doi:10.1136/bjsm.2008.049346

Copyright @ 2008 BMJ Publishing Group Ltd \& British Association of Sport and Exercise Medicine.

Publisher URL: http://bjsm.bmj.com/cgi/content/full/42/12/996

This paper is posted at ScholarlyCommons. https://repository.upenn.edu/bioethics_papers/62

For more information, please contact repository@pobox.upenn.edu. 
Does the biomedical revolution spell the end of sport?

\section{Comments}

Caplan, A L Does the biomedical revolution spell the end of sport? Br J Sports Med 2008 42: 996-997 doi:10.1136/bjsm.2008.049346

Copyright @ 2008 BMJ Publishing Group Ltd \& British Association of Sport and Exercise Medicine.

Publisher URL: http://bjsm.bmj.com/cgi/content/full/42/12/996 


\section{Does the biomedical revolution spell the end of sport?}

A L Caplan

Br. J. Sports Med. 2008;42;996-997; originally published online 18 Sep 2008; doi:10.1136/bjsm.2008.049346

Updated information and services can be found at:

http://bjsm.bmj.com/cgi/content/full/42/12/996

\section{These include:}

References This article cites 4 articles, 2 of which can be accessed free at: http://bjsm.bmj.com/cgi/content/full/42/12/996\#BIBL

\section{Rapid responses You can respond to this article at:} http://bjsm.bmj.com/cgi/eletter-submit/42/12/996

Email alerting Receive free email alerts when new articles cite this article - sign up in the box at service the top right corner of the article

Topic collections Articles on similar topics can be found in the following collections

$$
\text { Boxing (32 articles) }
$$

\section{Notes}

To order reprints of this article go to:

http://journals.bmj.com/cgi/reprintform

To subscribe to British Journal of Sports Medicine go to:

http://journals.bmj.com/subscriptions/ 


\section{Does the biomedical revolution spell the end of sport?}

\section{A L Caplan}

Department of Medical Ethics, University of Pennsylvania, 3401 Market Street, Suite 320, Philadelphia, 19104-3308, USA

Correspondence to: A L Caplan, Department of Medical Ethics, University of Pennsylvania, 3401 Market Street, Suite 320, Philadelphia, 19104-3308, USA; caplan@ mail.med.upenn.edu

Accepted 28 August 2008 Published Online First 17 September 2008
Many professional and amateur sports including track and field, weight-lifting, boxing, canoeing, professional baseball and professional cycling have suffered scandals involving steroids and human growth hormone (HGH) and have done so for many years. ${ }^{1-4}$ It seems self-evident that the use of steroids and HGH is a problem. The amount of media and political attention paid to steroids and other pharmacological forms of enhancement in sports, such as the use of blood doping and stimulants, suggest that biochemical enhancement is one of the greatest moral problems the world faces.

Well, OK, upon deeper reflection, the challenge of getting the steroids out of bicycle racing is not on the same moral plane as eliminating poverty or AIDS. Still, many people all over the world seem to think that the latest generation of performanceenhancing substances threatens the very integrity of sport. There has been a burst of writing in recent years making precisely this case and the budget and clout of the World Anti-Doping Agency (WADA) and similar policing agencies are growing, reflecting the view that chemical enhancement and fair competition cannot coexist.

In one sense, the argument that the current techniques for enhancing sports performance threaten sport is irrefutable. Synthetic steroids are dangerous. HGH in large amounts can be too. There is a real need to protect children who admire athletes, so as to prevent them from taking serious risks with their health in imitating what their idols do or, in a few instances, from being forced by their own parents to engage in risky behaviour in order to succeed in athletics.

But, what if biomedical science could put the safety issue aside? Someday, probably soon, there will be drugs that do what steroids do without any real risk of harm to the user. Forms of gene therapy are also being developed that will let us safely tweak ourselves and our offspring to perform athletic feats that are "swifter, higher and stronger" than ever before seen. ${ }^{5}{ }^{6}$ Would the world still want the interventions banned? Would doctors who offered such techniques be acting immorally?

John Harris, a British bioethicist, thinks not. In his book, Enhancing evolution, ' he argues that performance enhancement is not only ethically acceptable, but that it may be morally obligatory. Harris sees a legitimate role for the use of drugs and genetic engineering to improve performance in sport. He contends, safety aside, there are no convincing arguments against performance enhancement.?

In Harris's sports world, the genetically engineered, chemically enhanced and optimally trained should serve as our heroes. They will give us performances we really will never forget. And that, he argues, is the whole point of sport, so there is nothing wrong with enhanced performance. Or is there?

Harris's defence of performance enhancement stands in stark contrast to the efforts of sports authorities, medical organisations and prosecutors all over the world to vigorously chase down and defrock of honours any athletes who have used performance-enhancing substances. Are the prosecutions really persecutions? Should not adult athletes be free to take the risks they want to take in pursuit of their athletic goals? And when safety goes off the table, should performance enhancement simply be accepted as the future of sport? Are those who want seconds shaved off the time it takes to run a mile, high jumpers who can clear 3 metres, or baseball sluggers capable of smashing 100 or more home runs in a single season really all that interested in whether these records can be achieved without enhancement? There were few complaints about the effect of the latest swimming garb, as swimmers at the recent Olympics again and again destroyed previous world records by significant margins. ${ }^{8}$ Does sports medicine need to get ready for a not so distant day when it manages a thriving trade in performance-enhancing substances?

Maybe Harris is wrong. Sports, contrary to his view, involve more then seeing who performs best.

One of the most interesting critics of pharmacological enhancement in sport is Harvard political scientist Michael Sandel, who has argued ${ }^{10}$ that the causal role of human agency plays a key role in substantiating our admiration of athletic performance. In commenting on drug use in baseball he observes that:

\footnotetext{
"...as the role of (drug) enhancement increases, our admiration for the new achievement fadesor, rather, our admiration for the achievement shifts from the player to his pharmacist". ${ }^{10}$
}

Sandel is clearly on to something when he argues that chemically produced performance enhancement undermines our willingness to esteem the drug-addled performances of the recent winners of the Tour de France or the track successes of a Ben Johnson or a Marion Jones. Do we value a connection between effort and outcome? I think we do.

Every once in a while someone wins the lottery or finds an old heirloom worth a lot of money in the attic and no one seems to mind that they have advanced themselves through luck, not exertion. But that is not true in sport. A lucky bounce or a gust of wind can determine the outcome, but athletes get praise for performance linked to effort, not simple luck. The whole point of sport is to try to reward effort, even if luck also plays a crucial 
role in the outcome. Big efforts that produce big performances get the praise; luck or fluke-driven performances just get noticed.

Sports performances are explicitly associated, by the nature of the rules governing the activity, with causal effort. Sport is defined by its rules and most - admittedly as a matter of history or culture-link effort and outcome. If someone simply takes a pill and solely as a result can lift a lot of weight it may be amazing. But it is only a weightlifter's willingness both to train and to show extraordinary effort under conditions similar to those facing other weightlifters that makes weightlifting an athletic achievement as opposed to an exhibition. Similarly, the high-tech swim suits used in Beijing and other swimming competitions in the past year do contribute to improved performance but they do not obviate the need for serious, sustained and strenuous training on the part of the swimmer. Outcomes don't define sport-the process leading to the outcomes does.

But the ability of technology to improve performance, whether by drugs on the engineering of equipment threatens the nature of sport in a different way. Not only must performance-enhancing technologies, whether biochemical, engineering or environmental leave plenty of room for effort, they also cannot drive too large a gap between the performances of the past and the performances of today. Assessment of effort under relatively controlled conditions provides the continuity that allows the comparison of athletic performance between events, across national boundaries and over the years. That continuity helps distinguish a sport from an exhibition. That is why short-circuiting one's way to success by pills or hormones or gene-tweaking undercuts the value of athletic performance, because both effort and continuity are required in sport to make it a sport. Performance A must be assessable against performance $B$, achieved in a different time and place, if we are to have a sport.

Every sport has its decisions to make about the affect of equipment on continuity. Aerodynamic helmets in cycling, luge or bob-sledding, more aerodynamic balls in golf, metal or wooden bats in baseball, hydrodynamic oars in rowing, clapper skates in ice-skating, LaZr suits in swimming, large-head racquets in tennis, and carbon fibre composites in pole vaulting are just some of the many engineering technologies that can so affect performance as to make comparability and continuity with previous performances impossible. Similarly, oxygen tents, highly controlled diets, portable telemetry, improved weighttraining equipment and a greater understanding of psychology may allow for environmental intervention that disrupts comparability and continuity. There is no hard and fast answer to how to handle this problem. Some sports are very sensitive to any engineering or environmental intervention and resist them. Others are more tolerant. But, the fact that sports struggle with the continuity problem reveals the fact that it is important to the nature of sport.

So perhaps sport can be saved from the next generation of performance enhancing tricks or techniques by conceding that sport is convention-bound and arbitrarily so but it is. Effort leading to performance and the continuity of performances across time are definitive of sport. Enhancement threatens to undercut the emphasis on effort and continuity demanded by the rules. Admittedly, engineering, environmental manipulation, genetic alteration or drug-induced biochemical changes can all undercut either effort or continuity, or both. Still, it is this tension in deciding what enhancement to permit that ensures the future of sport and promises some restriction over what athletes can do, even if safety is not a concern. But there is one more problem that modern science poses for sport and it has nothing to do with enhancement.

The problem with putting one's chips on continuity and effort is that as biomedical knowledge of human capabilities and aptitudes grows, sports asks us to value the random luck of the genetic lottery of life that gives some people genes for strength, others genes for superb vision and still others genes for unusual coordination. The genetic lottery is not fair. If that is so then why is the randomness that greatly determines what efforts athletes are capable of making something to be admired?

We are learning more and more about the ways in which genes and environment interact to produce behaviour, skills, talents and aptitudes. ${ }^{11}$ Looking for value in the natural distribution of talents and skills is like looking for the source of free will in the random nature of evolution or the Heisenberg uncertainty principle. Estimable value does not lurk in random luck. It is hard to see why our increasing knowledge that it is heredity and early fetal development that sets the table for performance will not undercut sport. If at one end drug-enhanced or technology-driven performance lurches toward becoming mere exhibition, then understanding the genetic basis of human skills and capabilities transforms sport into a version of aesthetics - something in which performance can be admired as beautiful but not as estimable. Strangely, the greatest threat in to the future of sport is not necessarily new drugs, gene therapy or better chemistry. The more knowledge we gain about the hereditary and developmental factors involved, the greater the threat to our ability to value performance as the result of anything other than random luck in the distribution of the hereditary materials that govern so much of what each person can achieve. ${ }^{12}$ Science does not destroy the possibility of effort but it may diminish our understanding of its role to the point where sport simply devolves into exhibition.

The good news for sports fans and doctors who assist athletes is that there may be a moral rationale for limiting performance enhancing drugs and techniques in sport. The bad news is that the increasing knowledge of the genetics, biochemistry and physiology of human abilities may make it difficult for sport to long endure.

\section{Competing interests: None.}

\section{REFERENCES}

1. Canadian Broadcasting Corporation. Greek lifters can go to Beijing despite steroid scandal. Published 17 June 2008. http://www.cbc.ca/olympics/weightlifting/story/ 2008/06/17/0lympics-news-weighlifting-drugs.html (accessed 12 September 2008).

2. Magnay J. Russia faces IOC action over drugs. The Age 2 August 2008. http:// www.theage.com.au/news/latest-news/russia-faces-ioc-action-over-drugs/2008/08/ 01/1217097535147.html (accessed 12 September 2008).

3. Macur J. Landis's positive doping test upheld. New York Times 21 September 2007. http://www.nytimes.com/2007/09/21/sports/sportsspecial1/21landis.html?_r= 1 \&oref = slogin (accessed 12 September 2008).

4. Wilson D, Schmidt MS. Steroid report cites 'collective failure'. New York Times 14 December 2007. http://www.nytimes.com/2007/12/14/sports/baseball/14mitchell. html?hp (accessed 12 September 2008).

5. Sweeney HL. Gene doping. Sci Am 2004;291:62-9.

6. Filipp F. Is science killing sport? Gene therapy and its possible abuse in doping. EMBO Rep 2007;8:433-5.

7. Harris J. Enhancing evolution. Princeton: Princeton University Press, 2007.

8. Dillman I. As swim records fall, high-tech suit faces scrutiny. LA Times 27 March 2008. http://articles.latimes.com/2008/mar/27/sports/sp-swim27 laccessed 12 September 2008)

9. Sandel M. The case against perfection. Cambridge, MA: Harvard University Press, 2007.

10. Sandel MJ. The case against perfection. The Atlantic.com April 2004. http://www theatlantic.com/doc/200404/sandel (accessed 12 September 2008).

11. Glazier AM, Nadeau JH, Aitman TJ. Genetics: finding genes that underlie complex traits. Science 2002;298:2345-49.

12. Skinner JS, Jaskolski A, Jaskolska A, et al. Age, sex, race, initial fitness and response to training: The HERITAGE Family Study. J App/ Physiol 2001;90:1770-6. 